\title{
EDITORIAL
}

\section{In This Issue: New Concepts for Diabetes and Chronic Disease Management}

\author{
Kurt C. Stange, $M D, P b D$, Editor \\ Ann Fam Med 2007;5:194-195. DOI: 10.1370/afm.711.
}

$\mathrm{T}$ his issue of Annals brings into view new ways of understanding chronic illness care ${ }^{1}$ and efforts to improve the quality of care. ${ }^{2-4}$ It identifies a possible new diabetes risk factor that is easily visible on physical examination, rather than requiring an expensive or invasive test. ${ }^{5,6}$ Research in this issue shows that the electronic medical record is not a panacea for improving chronic illness care ${ }^{7}$ and discovers a novel typology of 3 ways that high-performing practices achieve high-quality care. ${ }^{8}$

Four of these studies take place in practice-based research networks (PBRNs), ${ }^{1,5,7,8}$ and an additional study characterizes the increasing capacity of PBRNs. ${ }^{9}$ This research shows that amidst the growing recognition of the potential of PBRNs by outside investigators and by the National Institutes of Health Roadmap, ${ }_{1}^{10,11}$ there is a concomitant need to foster bottom-up participation ${ }^{12}$ by PBRN members to avoid unbalancing the partnerships that create the power of the PBRN to generate relevant, applicable new knowledge. ${ }^{13}$

Four of these articles debunk popular theoretical frameworks for understanding disease management and practice improvement, and propose more robust alternatives. ${ }^{2-4,7}$ By helping us to think differently, these authors provide hope for getting out of the current rut of large resource investment for small improvements.

Other important research in this issue uses a novel method to discover that the treatment effect size people desire is greater than the actual effect of popular treatments for upper respiratory tract infections. ${ }^{14}$

A clinical trial assesses the impact of an ingenious and intrepid intervention for adolescent mothers. ${ }^{15}$

An essay illustrates that self-importance can get in the way of effective leadership. ${ }^{16}$

\section{TRANSITION OF EDITORIAL TEAM}

The Annals is pleased to welcome Deborah Cohen, $\mathrm{PhD}$, to the editorial team as an associate editor. Dr Cohen, an assistant professor in the Department of
Family Medicine at Robert Wood Johnson Medical School, is a communication scientist with expertise in applying qualitative methods to understand communication in health care settings. She led the Robert Wood Johnson Foundation's Qualitative Research Guidelines Project (http://www.qualres.org) and is principal investigator of the evaluation for the Prescription for Health project.

Also with this issue, Benjamin Crabtree steps down as associate editor. We extend our deep thanks to him for his vital role in establishing and developing the Annals. He has tirelessly worked with authors to improve their work and with the editorial team to set the direction for the Annals. Dr Crabtree will continue his internationally recognized work in qualitative research methods and understanding health care systems as complex organizations. With Dr Cohen's expertise, the Annals will continue to be a home for strong qualitative and mixed methods research.

We encourage readers to participate in the Annals Journal $\mathrm{Club}^{6}$ and to share your insights by joining the Annals online discussion at http://www.AnnFamMed.org.

\section{References}

1. Parchman ML, Pugh JA, Romero RL, Bowers KW. Competing demands or clinical inertia: the case of the elevated hemoglobin A1c. Ann Fam Med. 2007;5(3):196-201.

2. Solberg LI. Improving medical practice: a conceptual framework. Ann Fam Med. 2007;5(3):251-256

3. Geyman JP. Disease management: panacea, another false hope, or something in between? Ann Fam Med. 2007;5(3):257-260

4. Soubhi H. Toward an ecosystemic approach to chronic care design and practice in primary care. Ann Fam Med. 2007;5(3):263-269.

5. Kong AS, Williams RL, Smith M, et al. Acanthosis nigricans and diabetes risk factors: prevalence in young persons seen in southwestern US primary care practices. Ann Fam Med. 2007;5(3):202-208.

6. Stange KC. Annals journal club: Acanthosis nigricans and diabetes risk factors. Ann Fam Med. 2007;5:(3):iii.

7. Crosson JC, Ohman-Strickland PA, Hahn KA, et al. Electronic medical records and diabetes quality of care: results from a sample of family medicine practices. Ann Fam Med. 2007;5(3):209-215. 
8. Feifer C, Nemeth L, Nietert PJ, et al. Different paths to high-quality care: three archetypes of top-performing practice sites. Ann Fam Med. 2007;5(3):233-241.

9. Tierney WM, Oppenheimer CC, Hudson BL, et al. A national survey of primary care practice-based research networks. Ann Fam Med. 2007;5(3):242-250

10. National Institutes of Health. NIH Roadmap for Medical Research. http://nihroadmap.nih.gov/initiatives.asp. Accessed 4 May 2007.

11. Dickinson P. Clinical and translational science awards: a potential source of support for primary care research. Ann Fam Med. 2006;4(6):567-568

12. Thomas P, Griffiths F, Kai J, O'Dwyer A. Networks for research in primary health care. BMJ. 2001;322(7286):588-590
13. Thomas P, Graffy J, Wallace $P$, Kirby M. How primary care networks can help integrate academic and service initiatives in primary care Ann Fam Med. 2006;4(3):235-239.

14. Barrett B, Harahan B, Brown D, Zhang Z, Brown R. Sufficiently important difference for common cold: severity reduction. Ann Fam Med. 2007;5(3):216-223.

15. Barnet B, Liu J, DeVoe M, Alperowitz-Bichell K, Duggan AK. Home visiting for adolescent mothers: 2-year follow-up effects on parenting, maternal life course, and primary care linkage. Ann Fam Med. 2007;5(3):224-232.

16. Couper ID. The impotence of being important - reflections on leadership. Ann Fam Med. 2007;5(3):261-262.

\section{CHANCE-OF-ADDRESS FORM FAMILY MEDICINE}

Please complete this form and mail to the following address or fax to Annals Circulation at 913-906-6080:

Annals of Family Medicine, Circulation Department, 11400 Tomahawk Creek Pkwy, Leawood, KS 66211-2672

Check if member of sponsoring organization: $\square$ AAFP $\square$ ABFM $\square$ STFM $\square$ ADFM $\square$ AFMRD $\square$ NAPCRG

ID number from label on your journal cover

OLD Information (Please print.)

Name

Company (if applicable)

Address (Street plus Apt or Ste)

City

Country $\quad$ Postal Code (9-digit ZIP for US)

Telephone

Fax

E-Mail
NEW Information (Please print.)

\begin{tabular}{ll}
\hline Name & \\
\hline Company (if applicable) & \\
\hline Address (Street plus Apt or Ste) & \\
\hline City & Postal Code (9-digit ZIP for US) \\
\hline Country & \\
\hline Telephone & \\
\hline E-Mail &
\end{tabular}

